\title{
Comparison of the Effectiveness of Leaf Extracts of Anredera cordifolia, Psidium guajava and Pogostemon cablin on Inhibitory Power Over Escherichia coli Bacteria
}

\author{
Comparación de la eficacia de los extractos de hojas de \\ Anredera cordifolia, Psidium guajava y Pogostemon cablin \\ en su poder inhibidor sobre la bacteria Escherichia coli
}

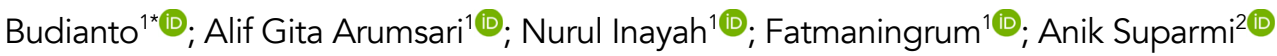

\section{JOURNAL VITAE \\ School of Pharmaceutical and Food Sciences ISSN 0121-4004 | ISSNe 2145-2660 University of Antioquia Medellin, Colombia}

Filliations

${ }^{1}$ Chemical Engineering, Al-Kamal Institute of Science and Technology, Jakarta, Indonesia

${ }^{2}$ SMK Negeri 3 Tarakan, KotaTarakan, Kalimantan Utara, Indonesia

*Corresponding Budianto

budianto_delta@yahoo.com

Received: 03 March 2021 Accepted: 07 September 2021 Published: 02 October 2021

\begin{abstract}
Background: the current research studies why it is effective using Anredera cordifolia, Psidium guajava, and Pogostemon cablin by the local community as a traditional medicine for diarrhea treatment caused by Escherichia coli bacteria. Objectives: We compared the inhibitor effectiveness of three leaf extracts against Escherichia coli; we also identified the anti-bacterial substances contained in leaf extracts. Methods: We determined the bacterial test activity using the "agar diffusion" method and the thin layer chromatography (TLC) as qualitative analysis for determining the anti-bacterial substances contained in the extract. Results: The Pogostemon cablin leaf extract contained terpenoids, phenolic, and flavonoids compound as bacterial inhibitors, and the comparison showed that Pogostemon cablin leaf extract had the greatest bacterial inhibition power. Conclusion: The antibiotic substances found in the leaf extracts of Anredera cordifolia, Psidium guajava, and Pogostemon cablin can be used as traditional medicine. The breakthrough was evidenced by the ability to inhibit Escherichia coli bacteria. This research shows that traditional medicine has ancient knowledge used by this paper.
\end{abstract}

Keywords: Anti-bacterial, Antimicrobial, TLC, agar diffusion, Anredera cordifolia, Psidium guajava, Pogostemon cablin, Escherichia coli

\section{RESUMEN}

Antecedentes: la presente investigación estudia la eficacia del uso de Anredera cordifolia, Psidium guajava y Pogostemon cablin por la comunidad local como medicina tradicional para el tratamiento de la diarrea causada por la bacteria Escherichia coli. Objetivos: Comparamos la eficacia inhibidora de los extractos de tres hojas contra Escherichia coli; también identificamos las sustancias antibacterianas contenidas en los extractos de hojas. Métodos: Determinamos la actividad de la prueba bacteriana mediante el método de "difusión en agar" y la cromatografía en capa fina (TLC) como análisis cualitativo para determinar las sustancias antibacterianas contenidas en el extracto. Resultados: el extracto de hoja de Pogostemoncablin contenía compuestos terpenoides, fenólicos y flavonoides como inhibidores bacterianos, y la comparación mostró que el extracto de hoja de Pogostemon cablin tenía el mayor poder de inhibición bacteriana. Conclusión: El contenido de sustancias antibióticas que se encuentran en el extracto de hoja de Anredera cordifolia, Psidium guajava y Pogostemon cablin puede utilizarse como medicina tradicional. Esto se evidencia por la capacidad de inhibir la bacteria Escherichia coli. Esta investigación muestra que la medicina tradicional tiene un conocimiento antiguo utilizado por este artículo.

Palabra clave: antibacteriano, antimicrobiano, Anredera cordifolia, Psidium guajava, Pogostemon cablin, Escherichia coli, TLC, difusión en agar 


\section{INTRODUCTION}

Escherichia coli is a gram-negative bacteria causative of diarrhea. The disease is related to digestive problems occasioned by a bacterial infection that spreads throughout the digestive organs. Diarrhea is still one of the important causes of morbidity and mortality worldwide [1, 2], and it is caused by the use of certain drugs [1], lactose, or fructose intolerance [2], consuming artificial sweeteners, and the most common causes other than viruses, namely bacteria [1]. This study selected Escherichia coli because of the most common cause of diarrhea in Indonesia, especially in areas with deplorable sanitation and densely populated areas, especially in urban areas.

There is a lot of cultural heritage and knowledge about medicinal plants in the Indonesian's lives, which are thought to have potential as natural antibacterials, including gandola leaves or binahong Basella alba L. They have antibacterial activity against Pseudomonas aeruginosa and $S$. aureus bacteria [3]. The ethanol and methanol extracts of guava leaves (Psidium guajava $L$ ) have antibacterial activity against $B$. cereus and $S$. aureus [4]. Efforts to find other alternatives in infection treatment are the use of traditional medicine [5]. Natural compounds that can be antibacterial often contain flavonoids, tannins, steroids, polyphenols, terpenoids, alkaloids, and saponins [4].

Extracts of water, acetone, and ethanol from tamarind leaves (Tamarindus indica L.) have antibacterial activity against Salmonella paratyphi, Bacillus subtilis, and Salmonella typhi bacteria [6]. Based on previous research, some of these plant leaves have unknown antibacterial activity against Escherichia coli bacteria. Therefore, it is necessary to screen for the antibacterial activity of extracts from several plant leaves in Indonesia against Escherichia coli bacteria, given its widespread.

Antibacterial are substances that can interfere with growth or kill bacteria by disrupting the microbial metabolism. The mechanisms of action of antibacterial compounds include inhibiting cell wall synthesis, integrity of bacterial cell wall permeability, work of enzymes, and synthesis of nucleic acids and proteins [6]. One of the antibacterial substances widely used is antibiotics, which are typically chemical compounds produced or derived by living organisms, including their synthetic analog structures, which in low levels can inhibit important processes in microorganisms' lives [7]. In this study, we used antibacterial substances obtained from local leaves that grow in Indonesia, such as binahong leaves (Anredera cordifolia), which Indonesians use as traditional medicine for diarrhea disease.

Some researchers found that Anredera cordifolia contains flavonoids readily soluble in polar solvents bound to sugars as glycosides and flavonoid aglycones [8]. Also, have other components such as saponins and alkaloids. This has inspired more specific research on Anredera cordifolia compounds, such as saponin [9], steroid/triterpenoid [10], flavonoids [11], and steroid in black-pigmented bacteria [12]. This study evaluated the antibacterial substances contained in Anredera cordifolia and compared them with other leaf extracts.

Research on antibacterial substances in Psidium guajava has expanded to various countries. Psidium guajava is effective against gram-positive bacteria $[13,14]$ and gram-negative bacteria $[15,16]$. The inconsistency of these results is very interesting to be evaluated in this study. Pogostemon cablin is widely recognized as a natural antibacterial agent in the pharmaceutical and clinical world [15]. An effective antibacterial agent for gram-positive bacteria [17,18]. Different results were also found by previous researchers $[19,20]$. This difference of opinion is reasonable because the analysis process involves the method and accuracy of the instrument so that Pogostemon cablin is suitable to be used as a sample in this study.

Previous researchers had used leaf extracts as antibacterial, such as Anredera cordifolia [10, 11], Psidium guajava [19,21,22], and Pogostemon cablin [16-18]. Munda et al. [21] compared several leaf extracts in India to make essential oils as antimicrobials used against various bacteria and fungi. Zuhaira [23] compared several plant extracts in Indonesia against Shigella species, where Psidium guajava extract had the highest bacterial inhibition power. Previous research efforts [24] had been conducted to get an antibacterial activity over Escherichia coli as the leading cause of diarrhea in Indonesia.

This study was intended to compare what has been stated by Zuhairai [23], saying that the antibacterial substance in Psidium guajava was the most effective against gram-negative bacteria. This research focused on the cause of diarrhea (Escherichia coli) by comparing the effectiveness of bacterial inhibitors such as Anredera cordifolia, Psidium guajava, and Pogostemon cablin. These three plants grow profusely in Indonesia and can be used as traditional medicine. Then, some comparisons to previous studies were made mainly to provide 
recommendations regarding specific uses of these leaves. However, the limitation of this study is on the tested bacteria, which was only Escherichia coli.

\section{MATERIALS AND METHODS}

\section{Material}

a. Anredera cordifolia, Psidium guajava and Pogostemon cablin leaves which mostly grow in Ciracas area of East Jakarta and are well known in treating diarrhea caused by Escherichia coli bacteria (based on diagnosis)

b. The strains Escherichia coli (Migula) Castellani and Chalmers from ATCC is a registered trademark of American Type Culture Collection

c. Ethanol 70\%, MH (Mueller Hinton) agar, sterile aquadest, BHI (Brain Heart Infusion) media, NA (Sodium Agar), filter paper, $\mathrm{NaCl}$, crystal violet, ammonium oxalate, iodine, potassium, acetone, chloramphenicol antibiotic capsules, ampicillin, tetracyclines, erythromycin, disk blank antibiotic DMSO (Dimethyl sulfoxide).

\section{Tools}

A set of maceration tools, glass tools (Pyrex Brand), Petri dishes (Pyrex Brand), Rotator (G-Lab Brand), Incubator (Memmert Brand), Bunsen Lamp, Vortex (Memmert Brand), Autoclave (Memmert Brand), Microscope (Olympus), Oven (Brand memmert), Lamminar Air Flow (LAF) cabinet (Astari Niagara), Sterile Ose, Analytical balance, Speader glass (One lab), Micropipette (Socorex) 10-50 $\mu \mathrm{L}$, Micropipette (Socorex) 100- $1000 \mu \mathrm{L}$, Micropipette (Socorex) 20-200 $\mu \mathrm{L}$, Dropper pipette, Yellow tips, Blue tips, sterile tweezers, TLC plate, UV-Vis Spectrophotometer (UV-1601 Shimadzu), Waterbath

\section{METHODS}

\section{Extraction procedure}

$100 \mathrm{~g}$ of dry powder was used for extraction by the maceration method for 72 hours, later filtered and concentrated using an evaporator for 1 hour. Then, it was put on a water bath to get a thick extract. Each extract was then prepared at a concentration of $20 \%(20 \mathrm{mg} / \mathrm{ml})$.

\section{Antibacterial activity test}

The method of testing for anti-bacterial activity refers to the POM RI [25].

Briefly, $200 \mu$ l of Escherichia coli strain was taken and then spread on a petri dish containing Muller Hinton Agar (MHA) media. A disk (6 mm) was infused with 15 $\mu \mathrm{l}$ from each extract stock. One disk was the negative control. The Petri dishes with bacteria and disks were incubated at $37^{\circ} \mathrm{C}$ for 24 hours, and afterward, the diameter of the inhibition zone was measured.

\section{Thin Layer Chromatography (TLC)}

The procedure refers to the Ministry of Education and Culture [26].

Previously, the TLC plate was activated by heating for 30 minutes, $60^{\circ} \mathrm{C}$. The leaf extracts were seeded using a capillary pipette, at $\pm 1 \mathrm{~cm}$ from the bottom end of the TLC plate. Then, the TLC plate was inserted in a tightly closed vessel containing the eluent solution (mobile phase). We waited until the eluent moved up from the plate bottom end to $10-15 \mathrm{~cm}$. Then, the plate was let dry at room temperature. The stains on the plate can be observed directly using UV lamps (254 and 366 $\mathrm{nm})$. The spots visualized under the UV lamp were marked, and the retention factor (Rf) was calculated.

\section{RESULTS}

The maceration test produced the extracts (Figure 1), which were still mixed with the solvent (ethanol) so that a filtering process must purify it to obtain the extract yield (\%) and extract residue (g). The filtering results can be seen in table 1 .

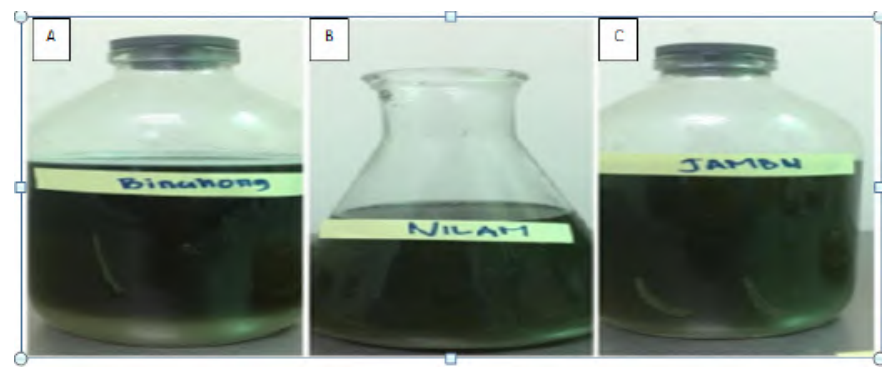

Figure 1. Leaf extracts yield of Anredera cordifolia (A), Pogostemon cablin (B), Psidium guajava (C) using $70 \%$ ethanol solvent. 
Table 1. Results of extract and yield filtering

\begin{tabular}{lccc}
\hline Sample & Powder leaf sample (gram) & Residue (gram, g) & Yield (\%) \\
\hline Psidium guajava & 100 & 6.81 & 6.80 \\
Pogostemon cablin & 100 & 9.73 & 9.80 \\
Anredera cordifolia & 100 & 13.93 & 13.93 \\
\hline
\end{tabular}

\section{Antibacterial activity test screening results}

This method used $6 \mathrm{~mm}$ blank disk (paper disks). Each extracted sample was prepared of $20 \%(200 \mathrm{mg} / \mathrm{mL})$, and $15 \mu \mathrm{L}$ were poured per disk.

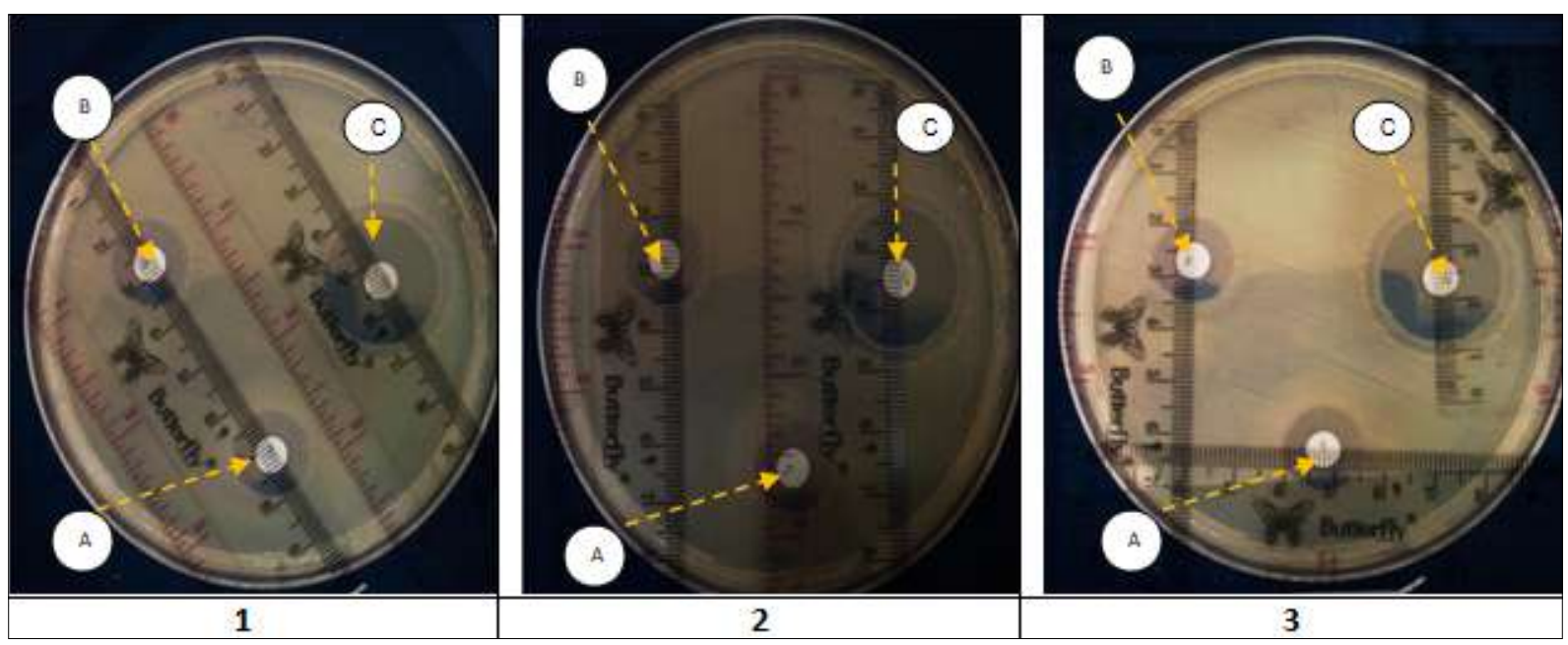

Figure 2. The bacterial inhibition tests. Observations made by triplicate. Each Petri dish shows the inhibition zones of three extracts (A) Anredera cordifolia, (B) Psidium guajava, (C) Pogostemon cablin.

Table 2. Results of the test for antibacterial activity of ethanol extract $70 \%$ against $E$. coli

\begin{tabular}{lcccc}
\hline \multicolumn{1}{c}{ Sample } & \multicolumn{4}{c}{ Inhibition Zone Diameter $(\mathbf{m m})$} \\
\hline & I & II & III & Average \\
\hline K: Negative Control & 6 & 6 & 6 & 6 \\
Anredera cordifolia & 16 & 15 & 15 & 15.3 \\
Psidium guajava & 15 & 15.4 & 15 & 15.2 \\
Pogostemon cablin & 29 & 28 & 30 & 29 \\
\hline
\end{tabular}

The test results showed that, from screening, the leaf extract that has the largest diameter of the inhibition zone is Pogostemon cablin extract. In detail, the zone of inhibition is $20 \%(\mathrm{mg} / \mathrm{L})$ at $15 \mu \mathrm{L} /$ disk at $29 \mathrm{~mm}$ ).

\section{Thin Layer Chromatography (TLC) Test Results}

TLC test showed that Pogostemon cablin contained inhibitory substances such as terpenoids, phenolics, and flavonoids. Psidium guajava contained terpenoids, flavonoids, and tannins. Meanwhile, the only substances found in Anredera cordifolia were polyphenols and saponins. The results of the complete analysis can be seen in table 3 . 
Table 3. Identification of Anti-Bacterial Compounds in Extracts

\begin{tabular}{|c|c|c|c|c|c|c|c|}
\hline \multirow{2}{*}{ Extract } & \multirow{2}{*}{$\begin{array}{c}\text { Smudge } \\
\text { value }\end{array}$} & \multirow{2}{*}{ UV 254} & \multirow{2}{*}{ UV 366} & \multirow{2}{*}{$\begin{array}{c}\text { Vanillin } \mathrm{H}_{2} \mathrm{SO}_{4} \\
\text { UV } 366\end{array}$} & \multirow{2}{*}{$\frac{\mathrm{FeCl}_{3}}{\text { UV } 366}$} & \multirow{2}{*}{$\begin{array}{c}\text { Cytoborate } \\
\text { UV } 366\end{array}$} & \multirow{2}{*}{ Information } \\
\hline & & & & & & & \\
\hline \multirow{2}{*}{ Pogostemoncablin } & 0.92 & Off & Orange & Purple & - & - & Terpenoids \\
\hline & 0.15 & Off & Yellow & - & Black & Yellow & Phenolic, Flavonoids \\
\hline \multirow{2}{*}{ Psidiumguajava } & 0.92 & Off & Orange & Purple & - & - & Terpenoids \\
\hline & 0.15 & Off & - & Greenish yellow & Blackish green & Greenish yellow & Flavonoids, Tannins \\
\hline \multirow{2}{*}{ Anrederacordifolia } & 0.92 & Off & Blue & - & Blackish green & - & Polyphenols \\
\hline & 0.15 & Off & - & Purplish blue & & & Saponins \\
\hline
\end{tabular}

The spot observation on TLC analysis was carried out at UV $254 \mathrm{~nm}$ and UV $366 \mathrm{~nm}$. Then, the spots were detected with several reagents $\left(\mathrm{FeCl}_{3}\right.$, vanillin $\mathrm{H}_{2} \mathrm{SO}_{4}$, and Cytoborate). TLC color detection reference refers to F.Geiss [27]. Orange spots indicated the presence of terpenoids at UV366, and purple color appeared after being sprayed with Vanillin $\mathrm{H}_{2} \mathrm{SO}_{4}$. Phenolic content in the form of black spots can be observed after being sprayed with $\mathrm{FeCl}_{3}$. Furthermore, flavonoid compounds can be observed through a greenish-yellow color change after being sprayed with acytoborate reagent. $\mathrm{Rf}$ 0.92 and 0.15 with $\mathrm{FeCl}_{3}$ reagent produces a blackish green color which indicated the presence of tannins. Saponins were shown in blue, purple, red, and yellow-brown colors after being sprayed with vanillin $\mathrm{H}_{2} \mathrm{SO}_{4}$. The polyphenols content was indicated by a blue color when observed at UV366 and a blackish green color when sprayed with $\mathrm{FeCl}_{3}$.

\section{DISCUSSION}

This study compared the effectiveness of inhibitory substances such as Anredera cordifolia, Psidium guajava, Pogostemon cablin leaf extracts over Escherichia coli. Decided to examine the efficacy, we performed a series of maceration processes and tested extracts activity against the bacteria. The test was conducted as a qualitative test (antibacterial agent) looking for the leaf extract with the highest effectiveness.

Filtering and purification results of leaf extracts mixed with ethanol (figure 1) are shown in table 1. Pogostemon cablin leaf extract has the largest residue, and Psidium guajava produces the smallest yield. The amount of residue is an indicator of the solute quantity in ethanol.

The choice of ethanol as a solvent refers to previous researchers because of its solubility effectiveness [16]. The dry leaf powder was obtained by sun-drying the leaves to reduce the water contained and keep the bacterial inhibitory compounds from evaporating because they are tightly bound to other compounds [28]. Our maceration process involved $70 \%$ ethanol solvent because it has better solubility [16]. At the extract purification stage, we must ensure no ethanol residue by re-evaporating the water batch at $55-60{ }^{\circ} \mathrm{C}$ [16].

The screening test was performed using the "agar diffusion" method, which determined the inhibition zone diameter produced by the leaf extract. Figure 2 shows three Petri dishes, spotted with the three leaves extracts. Pogostemon cablin had the largest inhibition zone diameter $(29 \mathrm{~mm})$, Anredera cordifolia and Psidium guajava had almost the same inhibition zone diameter (range $15 \mathrm{~mm}$ ). It indicates that Pogostemon cablin had doubled inhibitory power greater than Anredera cordifolia, Psidium guajava.

The diameter size difference of the inhibition zone interested us in conducting an in-depth analysis. Referring to table 3 , the findings of Pogostemon cablin containing terpenoids, phenolics, and flavonoids were in line with the results of Widyaningrum et al. [18]. Besides, the terpenoids, flavonoids, and tannins contained in Psidium guajava strengthen the findings of Zuhaira [23]. Furthermore, Anredera cordifolia also contained polyphenols and saponins, which confirms Indarto results [29]. Paying attention to the composition, both Pogostemon cablin and Psidium guajava had terpenoids and flavonoids. The difference was that phenolics were found in Pogostemon cablin while tannins were contained in Psidium guajava. Both were still in one compound (phenol), but tannins have poly bonds in the form of polyphenols. The next difference was that phenolics were more soluble in ethanol than tannins [28]. The extraction of tannins (polyphenols) in Anredera cordifolia using excess ethanol should be avoided because ethanol also has an inhibitory effect on Escherichia coli. In addition, the use of excess ethanol will require heating at higher temperatures 
or longer heating times. This causes the loss of some flavonoids because the vapor point of flavonoids is very close to ethanol [30].

From the description above, the errors were likely to occur if: a) the analyzed extract contained substances with a vast difference in boiling points (flavonoids and tannins); b) the solvent residue was left in the extract; and c) some substances evaporated along with the solvent (flavonoids) and substances that were not completely extracted (tannins). These conditions make it difficult for the researchers to determine compounds' quantity [31].

The main target of this study was the use of Anredera cordifolia, Psidium guajava, and Pogostemon cablin. So far, these plant leaves have limited use in animal feed. On the contrary, these leaves have rarely been used for medical or pharmaceutical purposes. This finding may convince local people regarding the antibacterial substances that could be used for traditional medicines. The pharmaceutical industry players, particularly in Indonesia, should be encouraged to make more efforts to diversify products made from these leaves. As we did not test for secondary or adverse effects on the compound content in the extract, further researchers concerning the same topic are suggested to do so.

\section{CONCLUSION}

The content of antibiotic substances found in the leaf extract of Anredera cordifolia, Psidium guajava, and Pogostemon cablin can be used as traditional medicine. This is evidenced by the ability to inhibit Escherichia coli bacteria. This research showed that traditional medicine has ancient knowledge used by this paper. The most effective anti-bacterial (Escherichia coli) is Pogostemon cablin, which has double inhibition power than Anredera cordifolia, Psidium guajava, Pogostemon cablin. Its utilization must be optimized for treating diarrhea due to Escherichia coli, the most significant cause of diarrhea for urban areas in Indonesia in the past two years. Pogostemon cablin contains terpenoids, phenolic, and flavonoids, almost the same as Psidium guajava (terpenoids, flavonoids, and tannins). The similarity in composition can be a gap in the subsequent analysis related to comparing the two by prioritizing the anticipation of errors caused by the nature of the antibiotic substance being analyzed.

\section{REFERENCES}

1. M. Farthing et al., "Acute Diarrhea in Adults and Children: A Global Perspective," "Journal of Clinical Gastroenterology: 2013; 47.1: 12-20. DOI: https://doi.org/10.1097/MCG.0b013e31826df662

2. C. L. F. Walker et al., "Global burden of childhood pneumonia and diarrhoea," Lancet, 2013; 381.9875: 1405-1416. DOI: https://doi. org/10.1016/S0140-6736(13)60222-6.

3. K. Allison, "Book Review: WHO global atlas of traditional, complementary and alternative medicine," J. R. Soc. Promot. Health, Kobe; 2005. 103p.

4. B. Biswas, K. Rogers, F. McLaughlin, D. Daniels, and A. Yadav, "Antimicrobial activities of leaf extracts of guava (psidium guajava L.) on two gram-negative and gram-positive bacteria," Int. J. Microbiol., 2013; 746165: 7 pages DOI: http://dx.doi. org/10.1155/2013/746165

5. J. B. Harborne and C. A. Williams, "Advances in flavonoid research since 1992," Phytochemistry. 2000; 55.6: 481-504. DOI: https:// doi.org/10.1016/S0031-9422(00)00235-1.

6. J. H. Doughari, "Antimicrobial Activity of Tamarindus indica Linn," Trop. J. Pharm. Res., 2006; 5.2: 597-603. DOl: https://doi. org/10.4314/tjpr.v5i2.14637. Available at http://www.tjpr.org

7. P. S. Stewart and J. W. Costerton, "Antibiotic resistance of bacteria in biofilms," Lancet. 2001; 358.9276: 135-138. DOI: https://doi. org/10.1016/S0140-6736(01)05321-1.

8. T. G. Taruscio, D. L. Barney, and J. Exon, "Content and Profile of Flavanoid and Phenolic Acid Compounds in Conjunction with the Antioxidant Capacity for a Variety of Northwest Vaccinium Berries," J. Agric. Food Chem., 2004; 52. 10:3169-3176. DOI: https://doi.org/10.1021/jf0307595

9. S. M. Astuti, M. Sakinah A.M, R. Andayani B.M, and A. Risch, "Determination of Saponin Compound from Anredera cordifolia (Ten) Steenis Plant (Binahong) to Potential Treatment for Several Diseases," J. Agric. Sci., 2011; 3.4: 224-232. DOl: http://dx.doi. org/10.5539/jas.v3n4p224

10. N. P. E. Leliqia, E. Y. Sukandar, and I. Fidrianny, "Antibacterial activities of Anredera Cordifolia (Ten.) V. Steenis leaves extracts and fractions," Asian J. Pharm. Clin. Res., 2017;3 .4: 224-232. DOI: https://doi.org/10.22159/ajpcr.2017.v10i12.21503

11. V. Wijaya, E. S. Maharani, H. A. Gunawan, and R. Puspitawati, "The efficacy of an infusion of binahong leaves (Anredera cordifolia (ten.) steenis) against wild strain black-pigmented bacteria," Int. J. Appl. Pharm., 2017; 9.2: 28-31. DOI: https://doi.org/10.22159/ ijap.2017.v9s2.08

12. E. S. Maharani, R. Puspitawati, and H. A. Gunawan, "Antibacterial effect of binahong (Anredera cordifolia (Ten.) Steenis) leaf infusion against black pigmented bacteria," in Journal of Physics: Conference Series, 2018; 1073. 03. DOI: https://doi. org/10.1088/1742 6596/1073/3/032013

13. M. D. Mahfuzul Hoque, M. L. Bari, Y. Inatsu, V. K. Juneja, and S. Kawamoto, "Antibacterial activity of guava (Psidium guajava L.) and neem (Azadirachta indica A. Juss.) extracts against foodborne pathogens and spoilage bacteria," Foodborne Pathog. Dis., 2007; 4.4: 481-488. DOI: https://doi.org/10.1089/fpd.2007.0040

14. A. Pachanawan, P. Phumkhachorn, and P. Rattanachaikunsopon, "Potential of Psidium guajava Supplemented Fish Diets in Controlling Aeromonas hydrophila Infection in Tilapia (Oreochromis niloticus)," J. Biosci. Bioeng., 2008; 106. 5: 419-424. DOI: https://doi.org/10.1263/jbb.106.419.

15. L. F. Hu et al., "GC-MS fingerprint of Pogostemon cablin in China," J. Pharm. Biomed. Anal., 2006; 42.2: 200-206. DOl: https:// doi.org/10.1016/j.jpba.2005.09.015. Available at https://www. sciencedirect.com/science/article/pii/S0731708505006278 
16. P. Chakrapani et al., "Comparitive studies on antibacterial activity of Patchouli [Pogostemon cablin (Blanco) Benth] and Geranium (Pelargonium graveolens) aromatic medicinal plants," African J. Biotechnol., 2014; 13.23: 2379-2384. DOI: https://doi.org/10.5897/ ajb12.1369

17. F. Peng, F. Wan, L. Xiong, C. Peng, M. Dai, and J. P. Chen, "In vitro and in vivo antibacterial activity of Pogostone," Chin. Med. J. (Engl)., 2014; 127. 23 : 4001-4005 doi: https://doi.org/10.3760/ cma.j.issn.0366-6999.20140494

18. S. Widyaningrum and S. Nurjanah, "NILAM TERHADAP BAKTERI ESCHERICIA COLI DAN PSEUDOMONAS AERUGINOSA Antibacterial Activity,"Gontor Agriculture. 2020; 6. 3:403-412. DOI: http://dx.doi.org/10.21111/agrotech.v6i3.4951

19. Y. Deguchi and K. Miyazaki, "Anti-hyperglycemic and antihyperlipidemic effects of guava leaf extract," Nutrition and Metabolism. 2010; 7, 9. DOI: https://doi.org/10.1186/1743-7075-7-9

20. Schnitzler P. Psidium Guajava (Guava): A Plant of Multipurpose Medicinal Applications. Med Aromat Plants. 2012; 01.04. DOI: http://dx.doi.org/10.4172/2167-0412.1000104

21. S. Munda, S. Dutta, S. K. Pandey, N. Sarma, and M. Lal, "Antimicrobial Activity of Essential Oils of Medicinal and Aromatic Plants of the North East India: A Biodiversity Hot Spot," J. Essent. Oil-Bearing Plants, 2019; 22.1: 105- 119. DOI: https://doi.org/10.1 080/0972060X.2019.1601032

22. D. L. Valle, J. I. Andrade, J. J. M. Puzon, E. C. Cabrera, and W. L. Rivera, "Antibacterial activities of ethanol extracts of Philippine medicinal plants against multidrug-resistant bacteria," Asian Pac. J. Trop. Biomed., 2015;5.7 :532-540 DOI: https://doi.org/10.1016/j. apjtb.2015.04.005

23. Zuhaira S, Nizam NM, Ridzuan P. The Efficacy of Psidium guajava Linn Leaf Extractsfrom Selangor Region Against Gram-Positive and Gram-Negative Bacteria. Folia Medica Indones. 2018; 54.4:294. doi: https://doi.org/0.20473/fmi.v54i4.10716
24. S. Ramli, S. Radu, K. Shaari, and Y. Rukayadi, "Antibacterial activity of ethanolic extract of syzygium polyanthum L. (Salam) leaves against foodborne pathogens and application as food sanitizer," Biomed Res. Int., 2017; vol.2017. ID 9024246: 13 pages, 2017. DOI: https://doi.org/10.1155/2017/9024246

25. Badan POM RI, "Peraturan Kepala Badan Pengawas Obat Dan Makanan Republik Indonesia Tahun 2011 Tentang Metode Analisis Kosmetika, first ed. BPOM, jakarta," pp. 1-92, 2011. 1-92p

26. Kemendikbud, Buku Informasi Melaksanakan Analisa Secara Kromatografi Konvensional Mengikuti Prosedur. jakarta; 2018. $1-80 p$

27. F. Geiss, Fundamentals of thin layer chromatography. United States: Huethig Publishing,Mamaroneck, NY, 1987. Available at https://www.osti.gov/servlets/purl/6723641

28. Charalampos Proestos, Michael Komaitis, Application of microwave-assisted extraction to the fast extraction of plant phenolic compounds, LWT - Food Science and Technology, 2008; 41.4: 652-659. DOI: https://doi.org/10.1016/j.Iwt.2007.04.013.

29. Indarto I, Narulita W, Anggoro BS, Novitasari A. Aktivitas Antibakteri Ekstrak Daun Binahong Terhadap Propionibacterium Acnes. Biosf J Tadris Biol. 2019;10.1: 67-78. doi: https://doi. org/10.24042/biosfer.v10i1.4102

30. M. R. V. Fernandes, A. L. T. Dias, R. R. Carvalho, C. R. F. Souza, and W. P. Oliveira, "Antioxidant and antimicrobial activities of Psidium guajava L. spray dried extracts," Ind. Crops Prod., 2014. 60: 39-44. DOI: https://doi.org/10.1016/j.indcrop.2014.05.049

[31] S. S. Dakappa, R. Adhikari, S. S. Timilsina, and S. Sajjekhan, "A REVIEW ON THE MEDICINAL PLANT PSIDIUM GUAJAVA LINN. (MYRTACEAE)," J. Drug Deliv. Ther., 2013. 3.2. DOI: https://doi. org/10.22270/jddt.v3i2.404. Available from: http://jddtonline.info/ index.php/jddt/article/view/404. 